\title{
STUDI KADAR LOGAM BERAT TIMBAL (Pb) PADA \\ KERANG HIJAU (Perna viridis) DI WILAYAH NGEMBOH, GRESIK DAN PPDI PELABUHAN PERIKANAN NUSANTARA BRONDONG, LAMONGAN, JAWATIMUR
}

\author{
Heavy Metal Content of Plumbum (pb) on Green Shells (Perna viridis) in The Region \\ of Ngemboh, Gresik and The PPDI Archipelago Fishery Port of Brondong, Lamongan, \\ East Java
}

\author{
Bagus Adi Priambodo ${ }^{\left({ }^{*}\right)}$, Muhammad Arief ${ }^{1}$, Boedi Setya Rahardja ${ }^{1)}$ \\ 1)Program Studi Akuakultur, Fakultas Perikanan dan Kelautan, Universitas Airlangga, \\ Surabaya, 60115, Indonesia \\ *korespondensi: bs_rahardja@yahoo.co.id
}

Diterima : 01 April 2021; Disetujui : 27 April 2021

\begin{abstract}
Marine pollution occurs due to the entry of industrial waste containing chemicals into the aquatic will cause changes to its ecological conditions. Pollutants contained in the waste are in the form of sediment nutrients, pesticides, pathogenic organisms, waste and heavy metals. The purpose of this study was to determine the content of heavy metal Pb in green mussels (Perna viridis), water, and sediments in the Ngemboh, Gresik area and in the waters of the Nusantara Brondong Fishery Port, Lamongan, East Java. The research is observational research with analysis data using linear regression, simple correlation (pearson) and ANOVA. The data collection was carried out by purposive random sampling. The heavy metal content of lead $(\mathrm{Pb})$ in green mussels in Ngemboh waters, Gresik has a heavy metal content of lead (Pb) of $0.871 \mathrm{ppm}, 0.199 \mathrm{ppm}, 0.161 \mathrm{ppm}$. The cause of the high content of heavy metal lead $(\mathrm{Pb})$ at station 1 is because it is close to the mouth of the Ngemboh river, where both organic and inorganic waste originate from local residents. Meanwhile, the content of the heavy metal lead $(\mathrm{Pb})$ in green mussels in the waters of the Indonesian fishing port in the archipelago of Brondong, Lamongan, has various values. The values of heavy metal lead (Pb) at both stations were $0.37 \mathrm{ppm}$ and $0.053 \mathrm{ppm}$. The content of heavy metal lead $(\mathrm{Pb})$ in green mussels has not exceeded the threshold specified in SNI 01-7387-2009, which means that green mussels are still fit for consumption.
\end{abstract}

Keywords: content of lead (Pb), green shells, water pollution

\begin{abstract}
ABSTRAK
Pencemaran laut terjadi disebabkan masuknya limbah industri yang mengandung bahan kimia ke perairan akan menimbulkan perubahan terhadap kondisi ekologisnya. Bahan pencemar yang terkandung dari buangan limbah berupa sedimen hara, pestisida, organisme patogen, sampah dan logam berat. Bahan pencemar dapat mengakibatkan turunnya kualitas perairan laut dan daya dukung lingkungan. Tujuan penelitian ini untuk Mengetahui kandungan logam berat $\mathrm{Pb}$ pada kerang hijau (Perna viridis), air, dan sedimen di wilayah Ngemboh, Gresik dan di perairan Pelabuhan Perikanan Nusantara Brondong, Lamongan, Jawa timur. Penelitian ini berupa observasi dengan analisis data menggunakan regresi linier, korelasi sederhana dan ANOVA. Pengambilan data dilakukan secara purposive random sampling. Kandungan logam berat timbal $(\mathrm{Pb})$ pada kerang hijau di perairan Ngemboh, Gresik sebesar 0,871 ppm, 0,199 ppm, 0,161 ppm. Penyebab tingginya kandungan logam berat timbal $(\mathrm{Pb})$ pada stasiun 1 karena berdekatan dengan muara sungai Ngemboh, dimana limbah organik maupun anorganik berasal dari penduduk setempat. Sedangkan kandungan logam berat timbal $(\mathrm{Pb})$ pada kerang hijau di perairan pelabuhan perikanan nusantara Brondong, Lamongan ini memiliki nilai yang bervariasi. Nilai logam berat timbal $(\mathrm{Pb})$ di kedua stasiun yaitu $0,37 \mathrm{ppm}$ dan 0,053 ppm. Kandungan logam berat timbal $(\mathrm{Pb})$ pada kerang hijau masih belum melebihi ambang batas yang detentukan SNI 01-7387-2009 yang artinya kerang hijau masih layak untuk dikonsumsi.
\end{abstract}

Kata kunci: Kerang hijau, pencemaran, Timbal $(\mathrm{Pb})$ 


\section{PENDAHULUAN}

Perairan ngemboh merupakan daerah penting bagi nelayan sekitar karena dijadikan sebagai area penangkapan perikanan. Berdasarkan surat keputusan menteri kelautan dan perikanan nomor 32/MEN/2010 tentang penetapan minapolitan menteri kelautan dan perikanan, PPN Brondong ditetapkan menjadi salah satu kawasan minapolitan di Jawa Timur. Pelabuhan Brondong ini terletak di Desa Brondong, Kecamatan Brondong, Kabupaten Lamongan, Provinsi Jawa Timur dengan posisi kordinat geografis pada 060 53' 30,81" LS dan 1120 17' 01,22" BT. PPN Brondong memiliki luas $8 \mathrm{Ha}$ (Laporan Statistik PPN Brondong Tahun 2014)

Pelabuhan Brondong didayagunakan untuk memenuhi kebutuhan hidup manusia terutama pemanfaatan sumber hayati seperti ikan dan kerang, selain aktivitas manusia dalam upaya pemanfaatan sumberdaya juga telah menimbulkan dampak negatif yaitu pencemaran logam berat, sehingga pencemaran logam berat yang masuk ke pelabuhan brondong juga semakin meningkat. Logam berat yang ada di pelabuhan brondong dapat berasal dari industri dan kegiatan transportasi laut yang semakin meningkat di sekitar perairan tersebut. Logam berat yang ada dalam badan perairan akan mengalami proses pengendapan dan terakumulasi dalam sedimen. Menurut Sudarwin (2008) timbal merupakan mineral yang tergolong mikroelemen dan berpotensi menjadi bahan toksik jika terakumulasi dalam tubuh biota laut yang ada dalam perairan (termasuk kerang yang bersifat sessil dan sebagai bioindikator.

Kerang hijau (Perna viridis) merupakan salah satu organisme yang menjadi parameter pencemaran perairan akibat dari kontaminasi logam berat. Kerang hijau (Perna viridis) termasuk binatang lunak
(Moluska) yang hidup di laut terutama pada daerah litoral, memiliki sepasang cangkang (bivalvia), berwarna hijau kebiruan. Insang berlapis-lapis (Lamelii branchia) dan memiliki kaki kapak (Pelecypoda) serta memiliki benang byssus. Kerang hijau (Perna viridis) adalah suspension feeder dapat berpindah-pindah tempat dengan menggunakan kaki dan benang byssus, hidup dengan baik pada perairan dengan kisaran kedalaman 1 meter sampai 7 meter, memiliki toleransi terhadap perubahan salinitas antara 27-35 per mil (Wang et al., 2011). Tujuan penelitian ini adalah untuk Mengetahui kandungan logam berat $\mathrm{Pb}$ pada kerang hijau (Perna viridis), air, dan sedimen di wilayah Ngemboh, Gresik dan di perairan Pelabuhan Perikanan Nusantara Brondong, Lamongan, Jawa timur.

\section{METODE PENELITIAN}

\section{Waktu dan Tempat}

Penelitian dilaksanakan di wilayah Ngemboh, Gresik dan Pelabuhan Perikanan Nusantara Brondong, Lamongan. Pengambilan sampel dilaksanakan pada bulan April-Juni 2020. Identifikasi baku mutu air laut, identifikasi logam berat pada sedimen, dan kerang hijau dilakukan di Balai Riset dan Standarisasi Industri (BARISTAND) Surabaya.

\section{Bahan dan Alat}

Bahan penelitian yang digunakan yaitu kerang hijau yang ditangkap nelayan pada titik stasiun yang telah ditentukan di wilayah Ngemboh, Gresik dan Pelabuhan Perikanan Brondong, Lamongan. Bahan yang digunakan untuk analisis kandungan Timbal (Pb) dalam penelitian ini adalah $\mathrm{H}_{2} \mathrm{SO}_{4}$, larutan $\mathrm{HNO}_{3}$ pekat, larutan $\mathrm{HCl}$, larutan baku Timbal $(\mathrm{Pb})$, aquades, sedimen dan air laut. 
Peralatan yang digunakan di lapangan antara lain GPS (Global Positioning System) untuk menentukan titik ordinat pada stasiun, botol sampel (volume 250 dan $600 \mathrm{~mL}$ ), ember, kamera digital, jaring, pancing, plastik pembungkus, coolbox, alat tulis, perahu nelayan, kertas label, tisu, peralatan untuk mengukur kualitas air adalah termometer, refraktometer, $\mathrm{pH}$ papper dan DO meter dan peralatan untuk menganalisis logam berat.

\section{Metode Penelitian}

Metode penelitian yang digunakan adalah metode observasi lapangan. Metode observasi adalah pengamatan terhadap suatu obyek yang diteliti baik secara langsung maupun tidak langsung untuk memperoleh data yang harus dikumpulkan dalam penelitian (Satori dan Komariah, 2009). Data hasil penelitian dianalisis secara regresi-kolerasi. Analisis data dilakukan untuk mengetahui hubungan kadar logam berat Timbal $(\mathrm{Pb})$ pada kerang hijau (Perna viridis), air laut, dan sedimen.

\section{Prosedur Kerja}

Tahap persiapan ini terdiri dari kegiatan studi literatur, mengumpulkan informasi berupa kondisi umum lokasi, persiapan alat dan bahan yang digunakan dalam penelitian.

\section{Pemilihan Waktu dan Lokasi \\ Pengambilan Sampel}

Pengambilan sampel di pelabuahan perikanan brondong dilaksanakan pukul 09.00-11.00 WIB pada bulan april sampai juni 2020. Pengambilan sampel penelitian dilakukan pada waktu perubahan musim dari kemarau ke penghujan (pancaroba). Koordinat lokasi pengambilan sampel penelitian pada Stasiun 1 yang merupakan titik awal pengambilan sampel di daerah yang dekat dengan industri, dan tempat bersandar kapal nelayan. Berjarak 200 meter dari daratan. Pengambilan sampel secara geografis terletak pada $6^{\circ} 86^{\prime} 88.260$ " LS 11229'59.790" BT. Stasiun ke 2 yang merupakan pengambilan sampel kedua di perairan Brondong. Stasiun ini masih dekat dengan industri dan tempat bersandar kapal. Berjarak 400 meter dari daratan. Pengambilan sampel di perairan pelabuhan. Brondong secara geografis terletak pada $6^{\circ} 87^{\prime} 04.839 "$ LS 112- 29, 65.957" BT.

Gambar 1. Peta lokasi pengambilan sampel penelitian

\section{Pengambilan dan Penanganan Sampel}

Sampel daging yang dibutuhkan yaitu 300 gram dari hasil kerang hijau yang telah ditangkap oleh nelayan. Hasil tangkapan sampel kerang hijau yang dibutuhkan berukuran 3-6 cm (Mufidah, 2004). Media tangkapan kerang hijau menggunakan metode menyelam dengan menggunakan kompresor. Selanjutnya dilakukan proses pengambilan sampel daging kerang hijau sebanyak 300 gram, kemudian dibawah ke laboratorium untuk dilakukan analisis kandungan logam berat Timbal (Pb).

\section{Pengukuran Parameter Lingkungan}

Pengukuran suhu menggunakan termometer. Pengukuran salinitas menggunakan refraktometer. Pengukuan nilai $\mathrm{pH}$ menggunakan $\mathrm{pH}$ meter. 
Sedangkan pengukuran data logam berat timbal $\mathrm{Pb}$ dilakukan dengan mengambil sampel air laut, sedimen dan kerang hijau dan dimasukkan ke dalam botol, kemudian sampel air didinginkan ke dalam coolbox (Marlian et al., 2015) sebelum dilakukan pengujian ke BARISTAND Surabaya. Alat dan tempat pengukuran kualitas air.

\section{Identifikasi Sampel}

Sampel yang sudah diambil kemudian dibawa ke laboratorium BARISTAND Surabaya untuk diidentifikasi. kemudian uji menggunakan metode Atomic Absorption Spectrophotometry (AAS) serta parameter air meliputi suhu, $\mathrm{DO}, \mathrm{pH}$, dan salinitas.

\section{Analisis Data}

Penelitian ini terdiri dari tiga variabel yaitu kandungan timbal pada sampel air, sedimen dan daging kerang hijau. Data penelitian dianalisis secara deskriptif dengan membandingkan dengan nilai baku mutu air, sedimen dan biota kerang hijau.

\section{HASIL DAN PEMBAHASAN}

Hasil penelitian yang telah dilakukan di perairan Ngemboh, Gresik dan Pelabuhan Perikanan Nusantara Brondong, Lamongan, diperoleh data kandungan logam berat timbal $(\mathrm{Pb})$ pada air, sedimen dan kerang hijau (Perna viridis) yang dapat dilihat pada Tabel 1 dan Tabel 2.

Hasil penelitian ini didapatkan nilai kandungan logam berat timbal $(\mathrm{Pb})$ pada kerang hijau di perairan Ngemboh, Gresik antara $0,012-0,129$. Nilai logam berat timbal $(\mathrm{Pb})$ pada kerang hijau paling tinggi diperoleh di stasiun 1 yaitu $0,129 \mathrm{mg} / \mathrm{kg}$, sedangkan hasil analisis logam berat timbal $(\mathrm{Pb})$ di ketiga stasiun pengambilan sampel antara 0,055-0,3 ppm (Tabel 1). Hasil logam berat timbal $(\mathrm{Pb})$ pada sedimen di ketiga titik yaitu antara 1,175- 2,023 ppm. Nilai ini belum melebihi ambang batas yang ditentukan yaitu $36 \mathrm{ppm}$.

Hubungan antara logam berat timbal $\mathrm{Pb}$ ) pada air dengan kerang hijau selama penelitian ditunjukkan dengan nilai koefisien korelasi $(R)$ yaitu 0,94 yang artinya berkorelasi sangat kuat $(075>R>0,99)$ dan memiliki arah korelasi positif. Nilai $R^{2}$ yang merupakan koefisien determinasi didapatkan hasil sebesar 0,88 yang artinya perubahan kandungan logam berat timbal $(\mathrm{Pb})$ pada air $(\mathrm{X})$ memiliki peran terhadap perubahan kandungan logam berat timbal $(\mathrm{Pb})$ pada kerang hijau $(\mathrm{Y})$ sebesar $88 \%$, sedangkan $12 \%$ dipengaruhi oleh faktor lainnya. Persamaan regresi yang terbentuk yaitu $Y=0,03+0,49 \mathrm{X}$ dengan tanda $(+)$ menunjukkan apabila konsentrasi logam berat timbal $(\mathrm{Pb})$ pada air naik maka konsentrasi logam berat timbal $(\mathrm{Pb})$ pada kerang hijau juga akan naik.

Tabel 1. Kandungan logam berat timbal $(\mathrm{Pb})$ pada air, sedimen dan kerang hijau (Perna viridis) di perairan Ngemboh, Gresik

\begin{tabular}{cccc}
\hline \multirow{2}{*}{ Stasiun } & \multicolumn{3}{c}{ Kandungan Logam Berat Timbal $(\mathrm{Pb})$} \\
\cline { 2 - 4 } & Air & Sedimen & Kerang Hijau \\
\hline 1 & 0,300 & 1,919 & 0,871 \\
2 & 0,061 & 1,175 & 0,199 \\
3 & 0,055 & 2,023 & 0,161 \\
\hline Baku mutu timbal $(\mathrm{Pb})$ & $0,005 \mathrm{ppm}^{*}$ & $36 \mathrm{ppm}^{* *}$ & $1,5 \mathrm{mg} / \mathrm{kg}(\mathrm{ppm})^{* * *}$ \\
\hline
\end{tabular}


Tabel 2. Kandungan logam berat timbal (Pb) pada air, sedimen dan kerang hijau (Perna viridis) di Pelabuhan Brondong, Lamongan

\begin{tabular}{cccc}
\hline \multirow{2}{*}{ Stasiun } & \multicolumn{3}{c}{ Kandungan Logam Berat Timbal $(\mathrm{Pb})$} \\
\cline { 2 - 4 } & Air & Sedimen & Kerang Hijau \\
\hline 1 & 0,640 & 0,430 & 0,370 \\
2 & $<0,0012$ & 0,072 & 0,053 \\
\hline Baku mutu timbal $(\mathrm{Pb})$ & $0,005 \mathrm{ppm}^{*}$ & $36 \mathrm{ppm}^{\star *}$ & $1,5 \mathrm{mg} / \mathrm{kg}(\mathrm{ppm})^{\star * *}$ \\
\hline
\end{tabular}

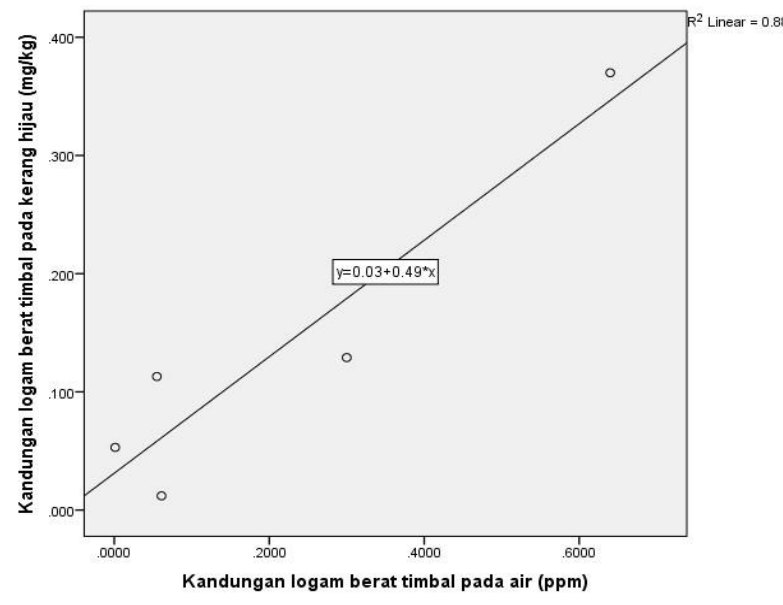

Gambar 2. Grafik hubungan kandungan logam berat timbal $(\mathrm{Pb})$ pada air dengan kerang hijau (Perna viridis)

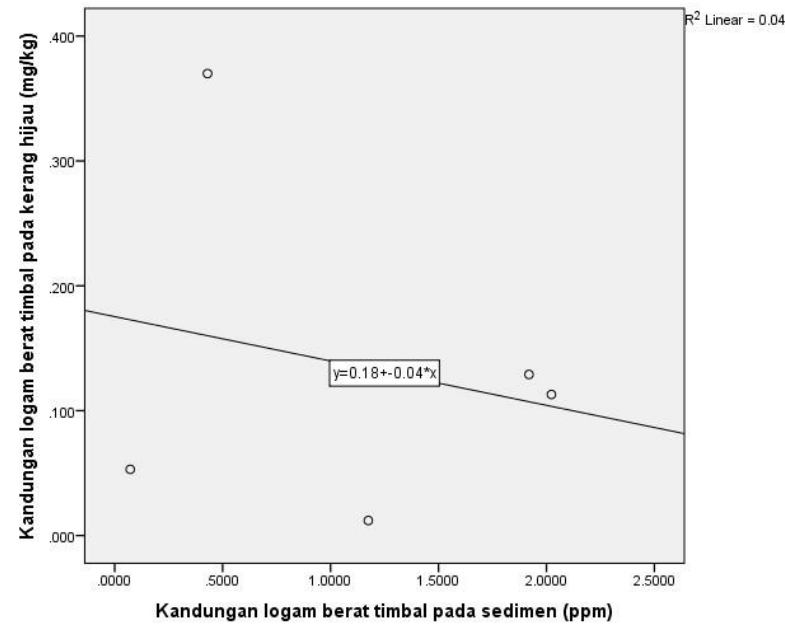

Gambar 3. Grafik hubungan kandungan logam berat timbal $(\mathrm{Pb})$ pada sedimen dengan kerang hijau (Perna viridis)

Hubungan antara logam berat timbal (Pb) pada sedimen dengan kerang hijau selama penelitian ditunjukkan dengan nilai koefisien korelasi $(R)$ yaitu 0,22 yang artinya berkorelasi sangat lemah $(0>R>0,24)$ dan memiliki arah korelasi positif. Nilai $R^{2}$ yang merupakan koefisien determinasi didapatkan hasil sebesar 0,04 yang artinya perubahan kandungan logam berat timbal
$(\mathrm{Pb})$ pada sedimen $(\mathrm{X})$ memiliki peran terhadap perubahan kandungan logam berat timbal $(\mathrm{Pb})$ pada kerang hijau $(\mathrm{Y})$ sebesar $4 \%$, sedangkan $96 \%$ dipengaruhi oleh faktor lainnya. Persamaan regresi yang terbentuk yaitu $Y=0,18+-0,04 \mathrm{X}$ dengan tanda $(-)$ menunjukkan apabila konsentrasi logam berat timbal $(\mathrm{Pb})$ pada sedimen naik maka konsentrasi logam berat timbal (Pb) pada kerang hijau akan mengalami penurunan.

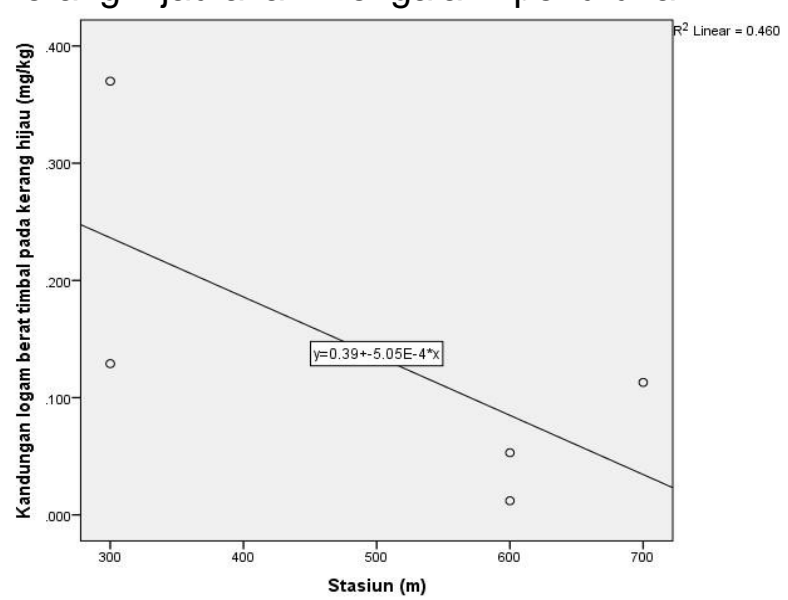

Gambar 4. Grafik hubungan kandungan logam berat timbal $(\mathrm{Pb})$ di setiap stasiun dengan kerang hijau (Perna viridis)

Hubungan antara logam berat timbal $(\mathrm{Pb})$ di setiap stasiun dengan kerang hijau selama penelitian ditunjukkan dengan nilai koefisien korelasi $(R)$ yaitu 0,67 yang artinya berkorelasi kuat $(0,5>R>0,74)$ dan memiliki arah korelasi positif. Nilai $R^{2}$ yang merupakan koefisien determinasi didapatkan hasil sebesar 0,46 yang artinya perubahan kandungan logam berat timbal $(\mathrm{Pb})$ di setiap stasiun $(\mathrm{X})$ memiliki peran terhadap perubahan kandungan logam berat timbal $(\mathrm{Pb})$ pada kerang hijau $(\mathrm{Y})$ sebesar $46 \%$, sedangkan $54 \%$ dipengaruhi oleh faktor lainnya. Persamaan regresi yang terbentuk yaitu $Y=0,39+-5,05 X$ dengan 
tanda (-) menunjukkan apabila jarak yang semakin jauh dari daratan maka konsentrasi logam berat timbal $(\mathrm{Pb})$ pada kerang hijau justru akan turun.

Kandungan logam berat timbal (Pb) yang terkandung dalam kerang hijau (Perna viridis) sangat dipengaruhi oleh kualitas air habitat dari kerang tersebut, apabila kerang hijau tidak dapat mentoleransi kondisi lingkungannya maka akan mengakibatkan kematian pada kerang. Hasil pengukuran kualitas air selama penelitian di wilayah perairan Ngemboh, Gresik.

Nilai rata-rata suhu di perairan Ngemboh, Gresik berkisar antara $29-30{ }^{\circ} \mathrm{C}$, sedangkan nilai rata-rata salinitas yaitu antara 28-30 ppm. Nilai tersebut masih dalam kondisi baik untuk kehidupan biota laut terutama untuk kerang hijau. Nilai ratarata $\mathrm{pH}$ yaitu berkisar antara 7-7,3, sedangkan arus di perairan Ngemboh, Gresik masih tergolong normal.

Nilai rata-rata suhu di perairan Pelabuhan Brondong, Lamongan berkisar antara $26,9-27,5{ }^{\circ} \mathrm{C}$, sedangkan nilai ratarata salinitas berikisar antara 21,5-31 ppm. Nilai tersebut masih dalam kondisi baik untuk kehidupan biota laut terutama untuk kerang hijau. Nilai rata-rata $\mathrm{pH}$ yaitu berkisar antara 7,58-7,64, sedangkan arus di perairan Pelabuhan Brondong, Lamongan masih tergolong normal.

Kandungan logam berat timbal $(\mathrm{Pb})$ pada kerang hijau di perairan Ngemboh, Gresik memiliki nilai kandungan logam berat timbal $(\mathrm{Pb})$ sebesar 0,871 ppm, 0,199 ppm, $0,161 \mathrm{ppm}$. Penyebab tingginya kandungan logam berat timbal $(\mathrm{Pb})$ pada stasiun 1 karena berdekatan dengan muara sungai Ngemboh, dimana limbah organik maupun anorganik berasal dari penduduk setempat. Muara sungai Ngemboh merupakan salah satu muara yang rentan terdampak limbah di daerah pedesaan terutama kota Gresik (Nadjib, 2013). Sedangkan kandungan logam berat timbal $(\mathrm{Pb})$ pada kerang hijau di perairan pelabuhan perikanan nusantara Brondong, Lamongan ini memiliki nilai yang bervariasi. Nilai logam berat timbal $(\mathrm{Pb}) \mathrm{di}$ kedua stasiun yaitu 0,37 ppm dan 0,053 ppm. Kandungan logam berat timbal $(\mathrm{Pb})$ pada kerang hijau masih belum melebihi ambang batas yang detentukan SNI 017387-2009 yang artinya kerang hijau masih layak untuk dikonsumsi.

Tingginya aktivitas penangkapan ikan oleh nelayan di stasiun 1 menyebabkan banyaknya oli kapal tumpah yang menjadikan pencemaran perairan. Aktivitas pengecatan kapal juga dapat mempengaruhi kadar logam berat karena menurut Rizkiana et al. (2017) terdapat kandungan loga berat timbal $(\mathrm{Pb})$ didalam cat yang berfungsi sebagai mempercepat pengeringan dan menghambat pengaratan pada permukaan logam atau besi Hal ini dapat mengindikasikan bahwa adanya pengaruh aktivitas kapal nelayan dapat menyumbang logam berat timbal $(\mathrm{Pb})$ menjadi sumber bahan pencemar apabila terlalu lama tertimbun dan terakumulasi di perairan. Selain itu pencemaran logam berat juga disebabkan oleh adanya kawasan industri, sehingga pencemaran perairan itu terjadi.

Tabel 3. Hasil pengukuran kualitas air selama penelitian di perairan Ngemboh, Gresik

\begin{tabular}{ccccc}
\hline Stasiun & Suhu $\left({ }^{\circ} \mathrm{C}\right)$ & Salinitas $(\mathrm{ppm})$ & $\mathrm{pH}$ & Arus \\
\hline 1 & 30 & 28,0 & 7,3 & Normal \\
2 & 30 & 29,3 & 7,0 & Normal \\
3 & 29 & 30,0 & 7,3 & Normal \\
\hline Baku mutu & $26-32$ & $27-35$ & $6,2-8,2$ & - \\
\hline
\end{tabular}


Tabel 4. Hasil pengukuran kualitas air selama penelitian di perairan Pelabuhan Brondong, Lamongan

\begin{tabular}{ccccc}
\hline Stasiun & Suhu $\left({ }^{\circ} \mathrm{C}\right)$ & Salinitas $(\mathrm{ppm})$ & $\mathrm{pH}$ & Arus \\
\hline 1 & 26,9 & 21,5 & 7,64 & Normal \\
2 & 27,5 & 31,0 & 7,58 & Normal \\
\hline Baku mutu & $26-32$ & $27-35$ & $6,2-8,2$ & - \\
\hline
\end{tabular}

Nilai logam berat timbal $(\mathrm{Pb})$ di perairan Ngemboh, Gresik dan pelabuhan perikanan Brondong, Lamongan memiliki hasil yang berbeda, di perairan Ngemboh, Gresik memiliki hasil logam berat timbal $(\mathrm{Pb})$ yang lebih tinggi dari pada pelabuhan perikanan Brondong, Lamongan. Hal ini dikarenakan banyaknya tempat industri yang berada pada sekitar perairan Ngemboh, Gresik yang menyebabkan banyaknya buangan limbah industri yang masuk ke perairan dan tingginya aktivitas masyarakat sekitar yang memanfaatkan wilayah perairan tersebut sebagai lahan mata pencaharian yang menggunakan kapal sehingga menyebabkan banyaknya tumpahan oli. Selain itu, dekatnya perairan Ngemboh dengan muara sungai juga dapat meningkatkan nilai logam berat timbal $(\mathrm{Pb})$ dikarenakan muara tersebut mendapat saluran pembuangan dari limbah organik dan anorganik.

Besarnya pengaruh antara kandungan logam berat timbal $(\mathrm{Pb})$ pada air laut dengan kerang hijau berdasarkan hasil perhitungan analisis regresi linier selama penelitian menunjukkan nilai koefisien korelasi (R) sebesar 0,94 yang tergolong dalam kriteria korelasi sangat kuat $(0,75>R>0,99)$ dan memiliki arah korelasi positif, artinya bahwa air laut signifikan mempengaruhi besar kecilnya konsentrasi timbal $(\mathrm{Pb})$ pada kerang hijau. Sedangakan besarnya pengaruh antara kandungan logam berat timbal $(\mathrm{Pb})$ pada sedimen dengan kerang hijau menunjukkan nilai koefisien korelasi (R) sebesar 0,22 yang tergolong dalam kriteria korelasi sangat lemah $(>0-0,24)$ dan memiliki arah korelasi positif, artinya sedimen pada perairan secara signifikan mempengaruhi besar kecilnya konsentrasi timbal $(\mathrm{Pb})$ pada kerang hijau.

Hubungan antara kandungan logam berat timbal $(\mathrm{Pb})$ dan sedimen umumnya mengikuti pola sebaran yaitu semakin menjauh dari pusat pencemar maka kandungan timbal $(\mathrm{Pb})$ dalam sedimen semakin rendah (Eshmat et al., 2014). Menurut Razo (2004) bahwa kandungan logam berat akan semakin menurun dengan semakin jauhnya jarak pengambilan sampel dengan sumber pencemar. Kandungan logam berat yang terdeteksi pada sedimen berbedabeda tergantung pada jarak dari setiap stasiun dengan pusat pencemar (Yona, 2013).

Besarnya nilai kandungan logam berat timbal $(\mathrm{Pb})$ pada kerang hijau dipengaruhi oleh kondisi perairan dan aktivitas manusia yang menyebabkan pencemaran. Logam berat timbal $(\mathrm{Pb})$ mudah terbawa oleh arus dan terakumulasi di dalam sedimen (Arief, 2014). Faktor-faktor yang dapat mendukung besar kecilnya kandungan logam berat timbal $(\mathrm{Pb})$ di air dan sedimen yaitu kualitas air, sifat fisik air, musim, dan sifat biologi dari kerang hijau (Perna viridis). Faktor lain yang mempengaruhi akumulasi logam berat timbal $(\mathrm{Pb})$ yaitu ukuran, usia dan habitat pada kerang itu sendiri. Ukuran kerang hijau yang didapat pada perairan berkisar antara 4-6,5 cm. Menurut Khusnul dkk. (2014) bahwa kerang hijau dibagi menjadi tiga kisaran ukuran 2-4 cm (kecil), 4-6 cm (sedang), 6-8 cm (besar). Kerang hijau yang diambil sebagai sampel penelitian termasuk dalam kategori sedang. Semakin besar pertumbuhan kerang, maka semakin tinggi konsentrasi logam berat pada kerang. 
Nilai korelasi yang didapatkan dari hasil perhitungan analisis statistik menggunakan SPSS 17 pada model summary dengan nilai korelasi (R) sebesar 0,94 untuk korelasi logam berat timbal $(\mathrm{Pb})$ pada air dengan kerang hijau, nilai (R) 0,22 untuk korelasi antara sedimen dengan kerang hijau, dan nilai (R) 0,67 untuk korelasi antara stasiun dengan kerang hijau. Menurut Dou et al. (2013) untuk menilai kekuatan korelasi nilai $\mathrm{R}$ (positif atau negatif) dengan nilai kisaran antara 0,90-1,00 mempunyai makna korelasi yang kuat. Artinya, nilai korelasi 0,94 menandakan titik pengambilan sampel kerang hijau memiliki hubungan sangat kuat terhadap kandungan logam berat, jadi nilai kandungan logam berat timbal (Pb) pada setiap stasiun memiliki perbedaan yang nyata.

\section{KESIMPULAN}

Berdasarkan penelitian yang telah dilakukan, dapat disimpulkan bahwa nilai kandungan logam berat timbal $(\mathrm{Pb})$ pada kerang hijau (Perna viridis) di perairan pelabuhan nusantara Brondong, Lamongan tidak melebihi ambang batas yang sudah ditetapkan. Nilai akumulasi timbal $(\mathrm{Pb})$ pada kerang hijau (Perna viridis) pada stasiun 1 dan 2 sebesar 0,37 ppm dan 0,053 ppm. Nilai tersebut belum melebihi ambang batas yang telah ditentukan menurut SNI 01-73872009 tentang batas maksimum cemaran logam berat timbal $(\mathrm{Pb})$ pada kerang.

\section{DAFTAR PUSTAKA}

Arief, M., Setiabudi, D., \& Rahardja, B. S. 2014. Analisis Perbedaan Nilai Konsentrasi Logam Berat Cadmium (CD) pada Rumput Laut (Eucheuma cottonii) di Perairan Pamekasan Dan Sumenep-Madura Jurnal IImiah
Perikanan dan Kelautan. 6(2): 201206.

Dou, Y., Li, J., Zhao, J., Hu, B., \& Yang, S. 2013. Distribution, enrichment and source of heavy metals in surface sediments of the eastern Beibu Bay, South China Sea. Marine pollution bulletin. 67(1-2): 137-145.

Khusnul, Y., N. T. Umar., L. Fachruddin, dan B. Batchtiar. 2014. Apakah Variasi Ukuran Panjang Cangkang Memengaruhi Konsentrasi Logam Timbal di Dalam Daging Kerang Hijau Perna viridis. MSP-10. Simposium Nasional I Kelautan dan Perikanan. Makassar.

Mufidah, 2004. Bioakumulasi Logam Hg, Pb dan Cd pada Kerang Hijau yang di Budidaya di Perairan Kamal dan Cilincing Jakarta. Skripsi. Institut Pertanian Bogor. Bogor.

Nadjib, M. M. 2013. Kelompok Kerja Sanitasi Kabupaten Gresik. Laporan Studi Environmental Health Risk Assesment (EHRA) Kabupaten Gresik. Gresik.

Razo, I. 2014. Arsenic and Heavy Metal Pollution of Soil, Water and Sediments in a Semi-Arid Cimate Mining Area in Mexico. Water, Air and Soil Pollution.152:129-152.

Rizkina , L., Sofyatuddin, K. \& Nurfafadilla., 2017, Analisis timbal (Pb) pada Sedimen danAir Laut Di Kawasa Pelabuhan Nelayan Gampong Deah Glumpang Kota Banda Aceh. Jurnal IImiah Mahasiswa Kelautan dan Perikanan Unsyiah. 2(1):89-96.

Sudarwin. 2008. Analisis Spasial Pencemaran Logam Berat (Pb dan Cd) pada Sedimen Aliran Sungai dari 
Tempat Pembuangan Akhir (TPA) Sampah Jatibarang Semarang. Tesis. Diterbitkan. Program Pascasarjana. Universitas Diponegoro. Semarang.

Wang, Y., Hu, M., Wong, W. H., Shin, P. K., \& Cheung, S. G. 2011. The combined effects of oxygen availability and salinity on physiological responses and scope for growth in the green-lipped mussel Perna viridis. Marine Pollution Bulletin. 63(5):255-261.

Yona, D., Vernandes, D., Kasitowati, R. D., \& Sari, S. H. J. 2020. Spatial Distribution and Contamination Assessment of Lead $(\mathrm{Pb})$ in the
Seawater and Surface Sediments of the Coastal Area of Prigi Bay, Trenggalek, East Java. Jurnal IImiah Perikanan dan Kelautan. 12(1):140148.

Zarkasih, F. R., T. Widyaleksono, C. p., A. Soegianto. 2019. Analisis Kandungan Logam berat $(\mathrm{Pb})$ cadmium (Cd), dan Seng (Zn) dan Kelayakan Konsumsi Kerang Hijau di Pantai Muncar Kabupaten Banyuwangi dan Muara Sungai Ujung Pangkah Kabupaten Gresik. Disertasi. Program Studi Teknik Lingkungan, Fakultas Sains dan Teknologi Universitas Airlangga. Surabaya. 87 hal. 